ERC Working Papers in Economics 14/04

June/ 2014

\title{
Exchange Rate Regimes and Business Cycles: An Empirical Investigation
}

\author{
Fatma P1nar Erdem \\ Central Bank of the Republic of Turkey \\ Ankara, TURKEY \\ E-mail: pinar.erdem@tcmb.gov.tr \\ Erdal Özmen \\ Department of Economics, Middle East Technical University, \\ Ankara, TURKEY \\ E-mail: ozmen@metu.edu.tr \\ Phone: + (90) 3122103044
}




\title{
EXCHANGE RATE REGIMES AND BUSINESS CYCLES: AN EMPIRICAL INVESTIGATION ${ }^{1}$
}

\author{
Fatma Pinar Erdem ${ }^{\mathrm{a}}$
}

and

\section{Erdal Özmen ${ }^{\mathrm{b}}$}

${ }^{a}$ Central Bank of the Republic of Turkey, Ankara, Turkey. e-mail: pinar.erdem@tcmb.gov.tr

\footnotetext{
${ }^{\mathrm{b}}$ Middle East Technical University, Department of Economics, Ankara, Turkey. e-mail: ozmen@metu.edu.tr
}

\begin{abstract}
This paper investigates the impacts of domestic and external factors along with exchange rate regimes on business cycles in a large panel of advanced and emerging market economies by employing panel logit, cointegration and autoregressive distributed lag model estimation procedures. The results for classical business cycles suggest that emerging market economies tend to experience much deeper recessions and relatively steeper expansions during almost the same duration. The probability of expansions significantly increases with exchange rate regimes flexibility. Our results, different from the bipolar view, strongly support exchange rate regime flexibility for both AE and EME other than the East Asian countries. The impacts of external real and financial shocks and domestic variables are significantly greater under managed regimes as compared to floats. Our results strongly suggest that the evolution and determinants of both classical business and growth cycles are not invariant to the prevailing exchange rate regimes.
\end{abstract}

Keywords: Business cycles, Exchange rate regimes, Emerging markets

JEL Classification: C33, E32, F33, F41

\footnotetext{
${ }^{1}$ The views expressed in the paper are those of the authors and should not be attributed to their institutions. We are grateful to Fatih Özatay, Elif Akbostancı and Kağan Parmaksız for their invaluable contributions to the paper. We thank them all. The usual disclaimers apply.

Corresponding Author: Erdal Özmen, Middle East Technical University, Department of Economics, 06531, Ankara, Turkey. Phone: +90 312210 3044, Fax: +90 312210 1244, e-mail: ozmen@ metu.edu.tr.
} 


\section{Introduction}

Does the exchange rate regime (ERR) matter for economic growth and business cycles? Do external factors are important for the evolution of economic growth and business cycles? Do the impacts of domestic and external factors on business cycles invariant to the prevailing ERR? Do the answers of these questions are all the same for advanced (AE) and emerging market economies (EME)? All these are amongst the basic questions of the empirical and theoretical international macroeconomic literature and the least disagreement appears to be the case for the final question. The answer for the final question is often "no" without an overwhelmingly mutually agreeing reason.

The optimal choice of an ERR has been a perennial question in international macroeconomics literature, albeit there is yet to be a consensus on the relative merits of the alternative regimes on growth and business cycles. The empirical literature based on developed countries, following the seminal papers by Baxter and Stockman (1989) and Flood and Rose (1995), argues that business cycles and variability of macroeconomic quantities are invariant to different ERRs. The results by Husain et al. (2005) suggest that this ERR neutrality is the case also for EMEs. The neutrality result, is not surprising according to Rose (2011) since choosing an ERR is, indeed, choosing a monetary policy. Consequently, the ERR, such as monetary policy, appears to be a veil for the long run real growth and the variability of real variables. The literature, however, is yet to investigate whether this long-run neutrality remains valid also in the short-run even for AE. The short-run neutrality may be expected to be justified by the New Classical or real business cycle frameworks but not necessarily by the NewKeynesian framework.

Under a flexible ERR, exchange rates adjust to absorb external shocks and thus economic performance may be expected to be more stable and stronger. Under international capital flows, ERR flexibility gives economies greater ability to pursue independent macroeconomic policy as postulated by the impossible trinity of international macroeconomics. In the same vein, international financial integration leads to countries with fixed ERRs import monetary policy of the center country. Fixed ERR, on the other hand, are often prone to currency crises (Fischer, 2008) with associated adverse growth affects. Given different insulation properties, the invariance of business cycles to alternative ERRs appears to be a puzzling result. This result, however, often tends to be a special case for developed countries. The results by Levy- 
Yeyati and Sturzenegger (2003) and Edwards (2011) indicate that emerging countries with more rigid exchange rates tends to experience slower growth and higher output volatility than countries with more flexible ERRs. Husain et al. (2005) find that the benefits of ERR flexibility increase as countries become richer and more financially developed. They suggest that floats are associated with higher growth for AE but the ERR neutrality appears to be the case for EME. Supporting the notion that exchange rate flexibility allows countries to accommodate external shocks, Broda (2004) and Edwards and Levy-Yeyati (2005) present evidence that terms of trade shocks get amplified in countries with more rigid ERRs. In the same vein, di Giovanni and Shambaugh (2008) find that high foreign interest rates have a contractionary effect on real output growth in developing or EMEs with pegged exchange rates.

Following Calvo, Leiderman and Reinhart (1993), there is now a considerable literature suggesting that, not only the domestic factors but also external factors such as global financial conditions determine the evolution of growth and business cycles in EME (Perri, and Neumeyer, 2005; Izquierdo, Romero and Talvi, 2008). In the same vein, the results by Gonzalez-Rozada and Levy-Yeyati (2008) and Özatay et al. (2009) suggest that soverign default risks proxied by the EMBI (Emerging Market Bond Index) spreads and thus real output fluctuations in EME are significantly triggered by global financial conditions. Kose, Otrok and Prasad (2012) report that global factors tend to play a more important role in driving domestic cycles in AE and EME than they do in other developing economies. Kose, Loungani, Terrones (2013) find that the sensitivity of national cycles to the global cycle is much higher during recessions than expansions. However, the issues that whether the impacts of external financial factors such as global liquidity conditions and global cycles along with domestic factors on business cycles are invariant to the prevailing ERRs and to different country groupings are yet to be empirically investigated ${ }^{2}$. In this context, the main aim of this paper is to investigate these issues empirically for a relatively large panel of AE and EME.

The plan of the rest of the paper is as follows. In Section II, we briefly present some empirical facts about business cycles and ERRs in AE and EME. To this end we consider not only the deviation or growth cycles but also the classical business cycles that are defined by Burns and Mitchell (1946), Bry and Boschan (1971) and Harding and Pagan (2002). Section III is devoted to an empirical investigation of the impacts of

\footnotetext{
${ }^{2}$ Hirata, Kose, and Otrok (2013) provide a comprehensive review of the recent literature analyzing the interactions between global, regional, group-specific and national cycles.
} 
domestic and external factors along with ERRs on business cycles in a large panel of AE and EME. Finally, section IV concludes.

\section{Business Cycles and Exchange Rate Regimes: Some Empirical Facts}

To investigate the relationships between ERRs and business cycles across different country groupings, we first consider classical business cycles defined by Burns and Mitchell (1946) and Bry and Boschan (1971) and which is consistent with the NBER dating of turning points. To this end, we use the BBQ (Bry, Boschan; Quarterly) algorithm introduced by Harding and Pagan (2002) and is an extended quarterly version of the method set out in Bry and Boschan (1971). According to the BBQ algorithm, a local peak (through) in $\mathrm{y}_{\mathrm{t}}$ occurs at time $\mathrm{t}$ if $\left\{\mathrm{y}_{\mathrm{t}}>(<) \mathrm{y}_{\mathrm{t} \pm \mathrm{k}}\right\}$ where $\mathrm{k}$ is the minimum duration of a phase, $y_{t}=\ln \left(Y_{t}\right)$ and $Y_{t}$ is the seasonally adjusted quarterly series of interest. Consistent with Bry and Boschan (1971), the algorithm defines that the minimum phase duration (k) is two quarters and a complete cycle lasts at least five quarters. Recent applications of the BBQ algorithm include Calderón and Fuentes (2014), Claessens, Kose and Terrones (2012), Altug et.al. (2012) and Altug and Canova (2012).

We consider the duration (D), amplitude (A), slope (S), the cumulative costs (C) or the gains $(\mathrm{G})$ and average compounded quarterly growth rate (AGR) of the classical business cycles as their main features. The duration of a recession (recovery) is the number of quarters (k) between a peak (through) and the next through (peak) of real GDP. The amplitude of a recession (recovery) is the change in $\mathrm{y}_{\mathrm{t}}$ from a peak (through) to the next through (peak). The slope/speed (S) of a cyclical phase is A/D. The AGR during a phase is computed as $\exp \left(\left(\mathrm{y}_{\mathrm{j}}-\mathrm{y}_{0}\right) / \mathrm{D}\right)-1$ where the subscripts $\mathrm{j}$ and 0 denote, respectively, the end and beginning of the phase. The cumulative effect of a phase (FP) is defined as:

$$
F_{P}=\sum_{j=1}^{k}\left(y_{j}-y_{0}\right)+\frac{1}{2} A_{P}
$$

where $A_{P}$ is the amplitude of the phase and $F_{P}$ represents the cumulative costs (gains) during a recession (expansion) which combines information on D and $\mathrm{A}$ as the area of the triangle of a cyclical phase.

Tables 1 and 2 present some descriptive statistics of the main features of the classical business cycles of AE and EME, respectively ${ }^{3}$. The average durations of the cycles are essentially the same between EME and AE. The duration of expansions is 23

\footnotetext{
${ }^{3}$ Sample of countries are reported Tables 1 and 2. The longest time period covered is from 1960:Q1 to 2013:Q1.
} 
quarters for $\mathrm{AE}$ and 22.9 quarters for EME and the difference is statistically insignificant with a probability ${ }^{4}$ value (p) being almost 1.0. The same case applies for the average duration of contractions which are 4 quarters for both AE and EME. The amplitudes (A), slopes $(\mathrm{S})$, the cumulative effects of phases $\left(\mathrm{F}^{\mathrm{P}}\right)$ and compounded quarterly growth rates (AGR) of the classical business cycles, on the other hand, appear to be substantially different between EME and AE. The average amplitude of contractions is $3.1 \%$ and $8.1 \%$ for $\mathrm{AE}$ and EME, respectively. The average amplitude of expansions is $23 \%$ and 34 $\%$ for $\mathrm{AE}$ and EME, respectively. Consistent with the results of Calderón and Fuentes (2014) and Claessens, Kose and Terrones (2012), EME tend to experience much deeper recessions and relatively steeper expansions during almost the same duration.

These results suggest that the pain of the recessions is more than twice whilst the gain of the expansions is around $50 \%$ more for EME than AE. The pain of contractions and the gain of expansions are almost the twice in EME compared to AE as suggested by the average slopes of the classical business cycles which are around 0.9 (expansions) and $-0.8 \%$ (recessions) for $\mathrm{AE}$ and $1.5 \%$ (expansions) and -1.9 (recessions) for EME. Consistently, average compounded growth rates (AGR) correspondingly for contractions and expansions are -0.8 and 0.9 for $\mathrm{AE}$ and -1.5 and 1.3 for EME. The cumulative effect (FP) of contractions is $-9.0 \%$ for AE whilst the effect is much sharper for EME with around 26 $\%$. The cumulative effect of expansions, consistent with the result for contractions, appears to be much higher for EME with $430 \%$ for $\mathrm{AE}$ and $753 \%$ for AE. All these results suggest that, whilst the duration of a phase is the same for EME and AE, the impact is much sharper both in terms of recessions and expansions in $\mathrm{EME}^{5}$. In the following section, we investigate whether this important difference is invariant to ERRs and the determinants of business cycles.

\footnotetext{
${ }^{4}$ The probability values (p) are estimated from the regressions of the business cycle feature (F) on a constant and a dummy variable taking unity for EME and zero for AE. Consequently, the dummy variable coefficient gives the difference of the average F of EME from that of the AE. The p-value is the p-level for the dummy variable coefficient not being statistically different from zero. All the differences, except for durations, are found to be statistically different from zero at the conventional $0.05 \mathrm{p}$-level.

5 The data for real GDP are from IMF-IFS and OECD. Our sample contains 21 advanced and 25 emerging market countries as listed by Tables 1 and 2 below. Note that, for most of the EME, the data are available only for the post-1980 period. For the eastern Europe countries, we have data only after the mid 1990's. To obtain comparable results, we consider the classical cycles of $\mathrm{AE}$ also for the post-1980sample. The results for the post1980 sample, with $\mathrm{D}=4.4, \mathrm{~A}=3.4, \mathrm{~S}=-0.8, \mathrm{AGR}=-0.8$ for contractions and $\mathrm{D}=24.0, \mathrm{~A}=20.0, \mathrm{~S}=0.8$ and $\mathrm{AGR}=0.8$ for expansions appear to be essentially the same with those for the whole sample for AE.
} 
Table 1. Classical Business Cycles in Advanced Countries: Basic Features

\begin{tabular}{|l|c|c|c|c|c|c|c|c|c|c|}
\hline & \multicolumn{1}{|c|}{ Contractions } \\
\hline & D & A & S & AGR & FP & D & A & S & AGR & FP \\
\hline Australia & 3.4 & -1.4 & -0.4 & -0.5 & -1.7 & 27.0 & 28.0 & 1.0 & 1.2 & 705.1 \\
\hline Austria & 3.6 & -2.1 & -0.6 & -0.6 & -5.3 & 24.4 & 21.2 & 0.9 & 0.8 & 338.0 \\
\hline Belgium & 3.7 & -1.8 & -0.5 & -0.5 & -4.8 & 17.7 & 15.1 & 0.9 & 1.0 & 178.6 \\
\hline Canada & 3.8 & -3.2 & -0.9 & -0.8 & -5.5 & 39.6 & 36.4 & 0.9 & 1.0 & 103.1 \\
\hline Denmark & 4.0 & -3.7 & -0.9 & -1.0 & -8.9 & 12.4 & 9.0 & 0.7 & 0.9 & 162.7 \\
\hline Finland & 6.0 & -6.1 & -1.0 & -0.9 & -29.3 & 35.5 & 34.7 & 1.0 & 1.0 & 851.1 \\
\hline France & 3.5 & -2.0 & -0.6 & -0.6 & -4.0 & 39.5 & 25.3 & 0.6 & 0.7 & 721.5 \\
\hline Germany & 3.6 & -2.0 & -0.6 & -0.6 & -4.5 & 14.1 & 13.5 & 1.0 & 0.9 & 146.2 \\
\hline Ireland & 5.0 & -4.9 & -1.0 & -0.6 & -23.2 & 26.5 & 35.8 & 1.4 & 0.9 & 887.6 \\
\hline Italy & 4.3 & -2.3 & -0.5 & -0.4 & -6.9 & 12.3 & 7.5 & 0.6 & 0.6 & 91.9 \\
\hline Japan & 3.6 & -5.1 & -1.4 & -1.2 & -15.4 & 20.4 & 29.3 & 1.4 & 1.0 & 856.7 \\
\hline Luxemburg & 2.5 & -4.3 & -1.7 & -1.5 & -5.4 & 22.0 & 23.0 & 1.0 & 0.8 & 557.4 \\
\hline Netherlands & 5.8 & -3.3 & -0.6 & -0.6 & -10.1 & 30.3 & 20.3 & 0.7 & 0.6 & 895.3 \\
\hline New Zealand & 3.4 & -2.6 & -0.8 & -1.2 & -4.1 & 21.2 & 20.5 & 1.0 & 1.1 & 292.1 \\
\hline Norway & 3.3 & -1.9 & -0.6 & -0.7 & -4.9 & 15.6 & 16.3 & 1.0 & 1.3 & 237.6 \\
\hline Portugal & 4.8 & -3.6 & -0.8 & -0.8 & -11.2 & 23.2 & 19.4 & 0.8 & 0.7 & 295.9 \\
\hline Spain & 4.2 & -2.1 & -0.5 & -0.4 & -7.3 & 24.5 & 20.8 & 0.9 & 0.7 & 433.3 \\
\hline Sweden & 5.4 & -2.8 & -0.5 & -0.7 & -10.0 & 17.4 & 14.7 & 0.8 & 0.9 & 214.7 \\
\hline Switzerland & 4.5 & -3.4 & -0.8 & -1.1 & -11.3 & 14.4 & 12.7 & 0.9 & 0.9 & 128.0 \\
\hline UK & 4.1 & -3.2 & -0.8 & -0.7 & -10.3 & 22.9 & 17.7 & 0.8 & 0.7 & 394.6 \\
\hline USA & 3.7 & -3.2 & -0.9 & -0.8 & -5.2 & 26.7 & 25.2 & 0.9 & 1.0 & 537.1 \\
\hline & & & \multicolumn{7}{|c|}{} & \multicolumn{7}{|c|}{} & & & & & \\
\hline Average & 4.1 & -3.1 & -0.8 & -0.8 & -9.0 & 23.0 & 23.2 & 0.9 & 0.9 & 429.9 \\
\hline Median & 3.8 & -3.2 & -0.8 & -0.7 & -6.9 & 22.9 & 22.9 & 0.9 & 0.9 & 338.0 \\
\hline
\end{tabular}


Table 2. Classical Business Cycles in Emerging Market Countries: Basic Features

\begin{tabular}{|c|c|c|c|c|c|c|c|c|c|c|}
\hline & \multicolumn{5}{|c|}{ Contractions } & \multicolumn{5}{|c|}{ Expansions } \\
\hline & $\mathrm{D}$ & A & $\mathrm{S}$ & AGR & FP & $\mathrm{D}$ & $\mathrm{A}$ & $\mathrm{S}$ & AGR & $\mathrm{FP}$ \\
\hline Argentina & 6.1 & -10.9 & -1.8 & 1.4 & -41.5 & 14.4 & 20.4 & 1.4 & -1.8 & 204.4 \\
\hline Brazil & 3.2 & -5.2 & -1.6 & -0.8 & -13.7 & 10.8 & 14.5 & 1.3 & 1.1 & 101.3 \\
\hline Chile & 3.3 & -10.0 & -3.0 & -2.6 & -28.6 & 30.8 & 44.7 & 1.5 & 1.4 & 996.4 \\
\hline Hong Kong & 3.2 & -5.1 & -1.6 & -1.7 & -11.3 & 20.3 & 34.7 & 1.7 & 1.7 & 548.7 \\
\hline Crotia & 6.5 & -5.6 & -0.9 & -0.8 & -27.3 & 18.3 & 24.7 & 1.3 & 1.5 & 428.1 \\
\hline Czech Republic & 5.0 & -3.7 & -0.7 & -1.0 & -10.2 & 14.2 & 17.4 & 1.2 & 1.6 & 209.2 \\
\hline Estonia & 4.0 & -9.8 & -2.5 & -2.2 & -30.0 & 17.0 & 28.2 & 1.7 & 1.3 & 381.2 \\
\hline Hungary & 3.3 & -3.2 & -1.0 & -0.9 & -7.8 & 15.0 & 11.7 & 0.8 & 0.6 & 216.6 \\
\hline India & 3.0 & -2.3 & -0.8 & -1.1 & -3.4 & 41.0 & 67.8 & 1.7 & 1.6 & 1487.5 \\
\hline Indonesia & 3.7 & -9.9 & -2.7 & -2.5 & -28.4 & 29.5 & 47.8 & 1.6 & 1.7 & 905.7 \\
\hline Israel & 3.0 & -7.0 & -2.3 & -1.7 & -50.7 & 19.3 & 26.0 & 1.3 & 1.4 & 253.4 \\
\hline S. Korea & 2.7 & -4.8 & -1.8 & -1.9 & -9.1 & 43.0 & 68.6 & 1.6 & 1.6 & 5980.3 \\
\hline Latvia & 7.0 & -28.9 & -4.1 & -3.2 & -123.3 & 16.3 & 30.7 & 1.9 & 2.4 & 485.1 \\
\hline Lithuania & 4.3 & -11.9 & -2.7 & -2.4 & -36.0 & 22.7 & 34.0 & 1.5 & 1.4 & 473.2 \\
\hline Malaysia & 3.0 & -6.7 & -2.2 & -1.3 & -13.5 & 32.0 & 53.3 & 1.7 & 1.7 & 1005.7 \\
\hline Mexico & 3.8 & -8.6 & -2.3 & -2.4 & -18.7 & 11.3 & 16.3 & 1.4 & 1.7 & 120.8 \\
\hline Peru & 3.8 & -9.4 & -2.5 & -2.6 & -22.8 & 10.1 & 19.3 & 1.9 & 2.1 & 137.0 \\
\hline Phillipines & 5.0 & -7.2 & -1.4 & -1.1 & -34.3 & 28.0 & 30.9 & 1.1 & 1.0 & 596.5 \\
\hline Romania & 4.7 & -3.9 & -0.8 & -0.7 & -19.0 & 11.3 & 16.6 & 1.5 & 1.2 & 208.9 \\
\hline Russia & 3.7 & -9.8 & -2.7 & -3.5 & -16.5 & 19.0 & 30.0 & 1.6 & 1.1 & 565.0 \\
\hline Singapore & 3.5 & -6.1 & -1.7 & -1.7 & -13.0 & 27.8 & 55.6 & 2.0 & 2.0 & 1044.5 \\
\hline Slovenia & 5.3 & -6.4 & -1.2 & -1.2 & -23.6 & 34.5 & 37.3 & 1.1 & 0.8 & 1116.6 \\
\hline South Africa & 5.7 & -3.2 & -0.6 & -0.6 & -11.1 & 25.4 & 26.4 & 1.0 & 1.1 & 623.2 \\
\hline Thailand & 5.5 & -12.1 & -2.2 & -2.1 & -38.1 & 41.7 & 66.7 & 1.6 & 1.8 & 492.9 \\
\hline Turkey & 3.7 & -10.6 & -2.9 & -2.0 & -23.3 & 19.2 & 33.1 & 1.7 & 1.5 & 377.3 \\
\hline Average & 4.2 & -8.1 & -1.9 & -1.6 & -26.2 & 22.9 & 34.3 & 1.5 & 1.3 & 758.4 \\
\hline Median & 3.8 & -7.0 & -1.8 & -1.7 & -22.8 & 19.3 & 30.7 & 1.5 & 1.5 & 485.1 \\
\hline
\end{tabular}


Table 3 reports the results of the maximum likelihood Logit estimation of the following equation:

$$
\mathrm{BC}_{\text {it }}=\beta_{1}+\gamma_{2} \mathrm{ERR}_{\mathrm{it}}+\gamma_{3} \mathrm{ERR}_{\text {it }}+\gamma_{4} \mathrm{ERR}_{\text {it }}+\gamma_{5} \mathrm{FF}_{\mathrm{it}}+\mathrm{u}_{\mathrm{it}}
$$

In the equation, $\mathrm{BC}$ is the phase of the classical business cycle which is 0 for contractions and 1 for expansions, the subscripts $i$ and $t$ are for country and time period, respectively and $\mathrm{u}_{\mathrm{it}}$ is the disturbance term. ERR(i) is the coarse de facto ERRs classification by Ilzetzki, Reinhart and Rogoff (2004) (IRR). IRR classify the ERR on a 14 scale with higher values denoting more flexible exchange rate arrangements. In the coarse classification, 1, 2, 3 and 4 respectively corresponds to hard pegs (full dollarization, currency boards and de facto peg regimes), limited flexibility (crawling peg or crawling band that is narrower than or equal to $+/-2 \%$ ), managed floating and freely floating ERR. In this context, ERR2, ERR3 and ERR4 are dummy variables taking unity for the prevailing ERR, correspondingly for the limited flexibility, managed floating and freely floating regimes in a particular quarter. IRR notes that classifying episodes of severe macroeconomic instability with very high inflation and exchange rate change as floating, intermediate or pegged may be misleading as they could be incorrectly attributed to the ERR. IRR classifies these episodes as "freely falling". In (1), FF is a dummy variable taking unity for freely falling episodes ${ }^{6}$. By construction the dummy variable, coefficients are measures of performance relative to the excluded pegged ERR conditional on the rest of the regressors.

Global real and financial conditions are often found to be amongst the important determinants of the evolution of growth and business cycles especially in EME (Izquierdo, Romero and Talvi, 2008; Gonzalez-Rozada and Levy-Yeyati, 2008 and Özatay et al., 2009). We consider the US growth cycle ( $\left.\mathrm{Y}^{\mathrm{C}} \mathrm{US}\right)$, estimated by the HodrickPrescott (HP) filter, to proxy the global real growth cycle. We consider the volatility implicit in U.S. stock options compiled by the Chicago Board Options Exchange (VIX) which is often taken as a measure of risk appetite of international investors -or alternatively the price of risk (Gonzalez-Rozada and Levy-Yeyati, 2008) as a proxy of

${ }^{6}$ IRR classification contains also episodes with dual market in which parallel market data is missing. These episodes are not contained in the sample of our empirical analyses. 
global financial conditions ${ }^{7}$. Table 3 reports also the results of the Logit estimation of (1) augmented with the US cycle ( $\mathrm{Y}_{\text {US }}^{\mathrm{C}}$ ) for the 1980:1-2013:2 quarterly data.

Table 3. Exchange Rate Regimes and Classical Business Cycles: Probit Results

\begin{tabular}{|c|c|c|c|c|c|c|c|}
\hline $\begin{array}{l}\text { Sample } \\
\text { (Eq.) }\end{array}$ & Constant & ERR2 & ERR3 & ERR4 & $\mathrm{FF}$ & $\mathrm{Y}^{\mathrm{C}}{ }_{\mathrm{US}}$ & Statistics \\
\hline All (3.1) & $\begin{array}{l}0.970 \\
(0.039)^{* *}\end{array}$ & $\begin{array}{l}0.072 \\
(0.056)\end{array}$ & $\begin{array}{l}0.107 \\
(0.056) * *\end{array}$ & $\begin{array}{l}0.222 \\
(0.079) * *\end{array}$ & $\begin{array}{l}-0.736 \\
(0.079)^{* *}\end{array}$ & & $\begin{array}{l}\mathrm{LR}=132.5[0.00] \\
\mathrm{R}=872, \quad \mathrm{E}=4424, \\
\mathrm{NT}=5296\end{array}$ \\
\hline All (3.2) & $\begin{array}{l}0.981 \\
(0.039) * *\end{array}$ & $\begin{array}{l}0.093 \\
(0.056) *\end{array}$ & $\begin{array}{l}0.124 \\
(0.057) * *\end{array}$ & $\begin{array}{l}0.200 \\
(0.088) * *\end{array}$ & $\begin{array}{l}-0.720 \\
(0.079)^{* *}\end{array}$ & $\begin{array}{l}12.840 \\
(1.502)^{* *}\end{array}$ & $\begin{array}{l}\mathrm{LR}=201.2[0.00] \\
\mathrm{R}=859, \quad \mathrm{E}=4303, \\
\mathrm{NT}=5162\end{array}$ \\
\hline EME (3.3) & $\begin{array}{l}1.050 \\
(0.072)^{* *}\end{array}$ & $\begin{array}{l}0.161 \\
(0.090)^{*}\end{array}$ & $\begin{array}{l}0.087 \\
(0.009)\end{array}$ & $\begin{array}{l}0.312 \\
(0.189) * *\end{array}$ & $\begin{array}{l}-0.798 \\
(0.099) * *\end{array}$ & & $\begin{array}{l}\mathrm{LR}=139.9[0.00] \\
\mathrm{R}=420, \quad \mathrm{E}=2215, \\
\mathrm{NT}=2635\end{array}$ \\
\hline EME (3.4) & $\begin{array}{l}1.056 \\
(0.072)^{* *}\end{array}$ & $\begin{array}{l}0.176 \\
(0.091)^{* *}\end{array}$ & $\begin{array}{l}0.110 \\
(0.091)\end{array}$ & $\begin{array}{l}0.324 \\
(0.191)^{*}\end{array}$ & $\begin{array}{l}-0.777 \\
(0.100)^{* *}\end{array}$ & $\begin{array}{l}12.156 \\
(2.181)^{* *}\end{array}$ & $\begin{array}{l}\mathrm{LR}=171.1[0.00] \\
\mathrm{R}=420, \quad \mathrm{E}=2215, \\
\mathrm{NT}=2635\end{array}$ \\
\hline $\begin{array}{l}\text { EME-EA } \\
(3.5)\end{array}$ & $\begin{array}{l}0.782 \\
(0.094)^{* *}\end{array}$ & $\begin{array}{l}0.404 \\
(0.124)^{* *}\end{array}$ & $\begin{array}{l}0.271 \\
(0.117) * *\end{array}$ & $\begin{array}{l}0.853 \\
(0.232) * *\end{array}$ & $\begin{array}{l}-0.485 \\
(0.118)^{* *}\end{array}$ & & $\begin{array}{l}\mathrm{LR}=104.4[0.00] \\
\mathrm{R}=298, \quad \mathrm{E}=1257, \\
\mathrm{NT}=1555\end{array}$ \\
\hline $\begin{array}{l}\text { EME-EA } \\
(3.6)\end{array}$ & $\begin{array}{l}0.783 \\
(0.095)^{* *}\end{array}$ & $\begin{array}{l}0.435 \\
(0.125) * *\end{array}$ & $\begin{array}{l}0.322 \\
(0.118) * *\end{array}$ & $\begin{array}{l}0.914 \\
(0.241)^{* *}\end{array}$ & $\begin{array}{l}-0.442 \\
(0.119) * *\end{array}$ & $\begin{array}{l}18.212 \\
(2.772)^{* *}\end{array}$ & $\begin{array}{l}\mathrm{LR}=148.8[0.00] \\
\mathrm{R}=298, \quad \mathrm{E}=1257, \\
\mathrm{NT}=1555\end{array}$ \\
\hline $\begin{array}{l}\text { EME (3.7) } \\
\text { East Asia }\end{array}$ & $\begin{array}{l}1.387 \\
(0.116)^{* *}\end{array}$ & $\begin{array}{l}-0.153 \\
(0.139)\end{array}$ & $\begin{array}{l}-0.113 \\
(0.148)\end{array}$ & $\begin{array}{l}-1.818 \\
(0.542)^{* *}\end{array}$ & $\begin{array}{l}-2.062 \\
(0.360)^{* *}\end{array}$ & & $\begin{array}{l}\mathrm{LR}=48.6[0.00] \\
\mathrm{R}=122, \quad \mathrm{E}=958, \\
\mathrm{NT}=1080\end{array}$ \\
\hline $\begin{array}{l}\text { EME (3.8) } \\
\text { East Asia }\end{array}$ & $\begin{array}{l}1.388 \\
(0.116)^{* *}\end{array}$ & $\begin{array}{l}-0.151 \\
(0.139)\end{array}$ & $\begin{array}{l}-0.111 \\
(0.148)\end{array}$ & $\begin{array}{l}-1.821 \\
(0.542) * *\end{array}$ & $\begin{array}{l}-2.066 \\
(0.360)^{* *}\end{array}$ & $\begin{array}{l}2.254 \\
(3.833)\end{array}$ & $\begin{array}{l}\mathrm{LR}=48.9[0.00] \\
\mathrm{R}=122, \quad \mathrm{E}=958, \\
\mathrm{NT}=1080\end{array}$ \\
\hline $\mathrm{AE} \quad$ (3.9) & $\begin{array}{l}0.924 \\
(0.046)^{* *}\end{array}$ & $\begin{array}{l}-0.092 \\
(0.075)\end{array}$ & $\begin{array}{l}0.073 \\
(0.077)\end{array}$ & $\begin{array}{l}0.235 \\
(0.087)^{*}\end{array}$ & & & $\begin{array}{l}\mathrm{LR}=48.9[0.00] \\
\mathrm{R}=453, \quad \mathrm{E}=2209, \\
\mathrm{NT}=2661\end{array}$ \\
\hline $\mathrm{AE} \quad(3.10)$ & $\begin{array}{l}0.937 \\
(0.046)^{* *}\end{array}$ & $\begin{array}{l}-0.059 \\
(0.075)\end{array}$ & $\begin{array}{l}0.084 \\
(0.078)\end{array}$ & $\begin{array}{l}0.192 \\
(0.099) * *\end{array}$ & & $\begin{array}{l}13.044 \\
(2.078)^{* *}\end{array}$ & $\begin{array}{l}\mathrm{LR}=47.5 \quad[0.00] \\
\mathrm{R}=439, \quad \mathrm{E}=2088, \\
\mathrm{NT}=2527\end{array}$ \\
\hline
\end{tabular}

Notes: The values in parentheses are the asymptotic standard errors. * and ** denote the significance at the 10 and $5 \%$, respectively. LR is the likelihood ratio statistic to test the null hypothesis that all the slope coefficients are jointly zero and [.] reports the p-value of the LR. R and $\mathrm{E}$ are the number of recession and expansion periods, respectively. NT is the number of observations for the sample.

The Logit results by Table 3 suggest that, compared to pegged ERR (ERR1), the probability of expansions substantially decreases with freely falling in $\mathrm{EME}^{8}$. This is not

\footnotetext{
${ }^{7}$ We considered also the external financial shocks proxied by VIX. As the results are found to be essentially the same those with $\mathrm{Y}_{\text {US }}^{\mathrm{C}}$, we prefer not to report them to save the space.

${ }^{8}$ The equations for AE do not contain FF as there is indeed no episode of freely falling for them. The sample for the equations with the US cycle variable does not contain the US data.
} 
surprising as freely falling $(\mathrm{FF})$ is defined for episodes of severe macroeconomic instability. For the whole sample of countries, the probability of expansion increases with ERR flexibility as suggested by positive and statistically significant ERR2 (limited flexibility), ERR3 (managed floating) and ERR4 (floating) coefficients in (3.1). For all the country groupings except the East Asian EME, a positive $\mathrm{Y}^{\mathrm{C}}{ }_{\mathrm{US}}$ representing better global real conditions, lead to a significant increase in the predicted probability of expansions. This supports the crucial importance of external factors for business cycles of both AE and EME. The result strongly favouring flexible ERR appears to be robust to the augmentation of the equation with the global factor (3.2). For the EME sample, the probability of expansions significantly increases with ERR flexibility (eqs. 3.3 and 3.4). Given the fact that, East Asian (EA) countries often implemented managed ERR, we also estimate the equations for the sample of EME excluding EA countries (EME-EA) and EA countries. The results preferring ERR flexibility is further supported by the EME-EA sample (eqs. 3.5 and 3.6). For the East Asian EME, on the other hand, the probability of expansion substantially decreases under a floating ERR (eqs. 3.7 and 3.8). For these countries, the performance of the other managed (limited flexibility, managed floating) regimes does not significantly different from that of the hard peg regimes. EME-EA countries appear to enjoy the benefits of the ERR flexibility much more than the EA countries. The impact of global real shocks is positive and significant for the EME-EA. Consistent with an argument that the they may be more sensitive to Chinese cycles, this impact tends to be substantially smaller (and insignificant) for the East Asian EME countries. For the sample of AE, flexible ERR (ERR4) outperforms the managed and fixed regimes (eqs. 3.9 and 3.10).

The results presented by Table 3, thus can be interpreted as strongly supporting ERR flexibility for both AE and EME other than EA. The bipolar prescription suggesting that countries should adopt free floats or hard pegs (Fischer, 2001) is not supported by the data. Our findings, however, are consistent with those of Ghosh, Ostry and Qureshi (2014) suggesting that macroeconomic (and financial) vulnerabilities are significantly greater under managed regimes as compared to floats. Our results for the whole EME and EMEAE samples may be interpreted as consistent with Levy-Yeyati and Sturzenegger (2003) and Edwards (2011) indicating that EME with more rigid exchange rates tends to experience slower growth than countries with more flexible ERRs. The invariance of the business cycles to ERR as suggested by Baxter and Stockman (1989), Flood and Rose (1995) and Husain et al. (2005) appears not to be the case even for AE. In the following 
section, we empirically investigate whether the determinants of the growth cycles differ between ERR and country groupings.

\section{Growth Cycles and Exchange Rate Regimes: Empirical Results}

In this section we proceed with the investigation of the determinants of growth cycles across different ERRs and country groupings. To this end, we start with the estimation of the following static equation for different country groupings and ERRs:

$$
y_{i t}=\beta_{0}+\beta_{1} Y^{C}{ }_{U S, t}+\beta_{2} \text { reer }_{i t}+\beta_{3} r_{i t}+u_{i t}
$$

In (2), $\mathrm{y}$ is the log. of seasonally adjusted real GDP, $\mathrm{Y}^{\mathrm{C}}$ US is the US cycle to proxy global real economic conditions, reer is the log. of real effective exchange rate, $\operatorname{rr}$ is $\ln (1+$ $\mathrm{RR} / 100$ ) with $\mathrm{RR}$ being the real domestic interest rate ${ }^{10}$. We then proceed by the estimation of the following reparametrised panel version of autoregressive distributed lag (PARDL) model (Pesaran et al., 1999 and Pesaran et al., 2001):

$$
\begin{aligned}
\Delta \mathrm{y}_{\mathrm{it}}= & \operatorname{\Theta ec}_{\mathrm{t}-1}+\varphi_{1} \Delta \mathrm{Y}_{\mathrm{US}, \mathrm{t}}^{\mathrm{C}}+\varphi_{2} \Delta \mathrm{Y}_{\mathrm{US}, \mathrm{t}-1}^{\mathrm{C}}+\varphi_{3} \Delta \mathrm{reer}_{\mathrm{it}}+\varphi_{4} \Delta \mathrm{reer}_{\mathrm{it}-1}+\varphi_{5} \Delta \mathrm{rr}_{\mathrm{it}}+\varphi_{6} \Delta \mathrm{rr}_{\mathrm{it}-1} \\
& +\varphi_{7} \mathrm{vix}_{\mathrm{t}}+\varphi_{8} \mathrm{vix}_{\mathrm{t}-1}+\mathrm{u}_{\mathrm{it}}
\end{aligned}
$$

where $\Delta$ is the first difference operator and ec (equilibrium/error correction term) are the stationary residuals from the estimation of (2) with $\Theta$ denoting the speed of adjustment. Note that, equation (3) contains also (log.) of VIX (volatility implicit in U.S. stock options compiled by the Chicago Board Options Exchange) to proxy the impact of global financial conditions. As already noted, the VIX is often taken as a measure of risk appetite of international investors -or alternatively the price of risk (Gonzalez-Rozada and LevyYeyati, 2006). According to Rey (2013) global financial cycles co-moves with the VIX both of which are important in creating boom in bust cycles in EME and AE. The vix and $\mathrm{Y}^{\mathrm{C}}$ us may be defined to represent external financial and real shocks, respectively.

The panel ARDL model is preferred since it enables to analyze empirically the longrun relationship along with short-run dynamics among the variables of interest when it is not known with certainty whether variables of interest are stationary $(\mathrm{I}(0))$, non-stationary

\footnotetext{
${ }^{9}$ GDP volume index series or Real GDP series from IFS.

${ }^{10}$ Real effective exchange rates are from the Bank for International Setlements (BIS) broad indices. For countries that do not have real effective exchange rates in BIS dataset, series are obtained from IFS. Real interest rates are computed by using money market rate or equivalent from IFS.
} 
(I(1)) or mutually cointegrated (Pesaran et al., 1999, 2001). The panel ARDL model is valid regardless of whether the regressors are exogenous or endogenous (Chudik, et al., 2013) and thus appears to be appealing potential endogeneity of the domestic variables could be important in the evolution of business/growth cycles ${ }^{11}$. In (3) the dependent variable, indeed defines, growth cycles ${ }^{12}$ and the use of it is consistent with the recent empirical studies including Harding and Pagan, 2003; Crucini et al, (2011), Boschi and Girardi, 2011, Levy Yeyati and Williams (2012), Kose, Otrok and Prasad (2012). This is also consistent with the view that business cycle synchronization depends on the moments of output growth (Harding and Pagan, 2004).

The fixed effects estimation (2) for different country groupings and ERRs are reported by Table 4. The results from (4.1) suggest that both the domestic (real exchange rates and interest rates) and foreign (the US cycle) significantly affect the evolution of real income in the whole sample of countries. Considering the result ${ }^{13}$ that all the variables in (2) is integrated of order 1 (I(1)) possibly except $\mathrm{Y}^{\mathrm{C}}{ }_{\mathrm{US}}$, the rejection of the nonstationarity of the residuals from the estimation of the equations in the table may be interpreted es supporting the presence of a cointegration relationship between them. Real exchange rate appreciations (an increase in reer) appear to be expansionary whilst real interest rate increase are contractionary for the whole sample of countries (4.2). The latter result is consistent with the earlier findings of the literature (Perri and Neumeyer, 2005 and di Giovanni and Shambaugh, 2008) and the former may indeed also be reflecting the Balassa-Samuelson affect.

\footnotetext{
${ }^{11}$ Following the global VAR approach by Pesaran et al., (2004) and Cesa-Bianchi et al., (2012), we maintain that the foreign variables (vix and the US cycle) are weakly exogenous for the parameters of interest. The evolution of the domestic variables, on the other hand, may not be exogeneous for the evolution of the real output dynamics and thus we considered also the cases with not containing the current values of them as explanatory variables in the estimated PARDL specifications. The results were essentially the same with those in this paper and thus not reported to save the space.

${ }^{12}$ The recent business cycle literature often maintains that the cycle can be represented by stationary deviations of the series from its permanent component and consequently uses filtering procedures such as Hodrick-Prescott (HP) in the standard applications. The results by Aguiar and Gopinath (2007), on the other hand, suggest that, shocks to trend growth are the primary source of fluctuations in EME. In the same vein, total factor productivity (TFP), which is often taken as the main driver of busines cycles, may follow a random walk process (Baxter and Crucini, 1995; Rabanal et al., 2011; Schmitt-Grohé and Uribe, 2011). Therefore, it may be argued that a stationary business cycle may not be a priorily taken as a generally accepted empirical regularity. Note that, as shown by Harding and Pagan (2005), $\Delta \mathrm{y}_{\mathrm{t}}$ is indeed a special case of the cycles estimated by filtering procedures including HP.

${ }^{13}$ Levin, $\mathrm{Li}$ and Chu (2002) panel unit root test results [p-values] with lag length 4 yielded 18.8 [0.00] for $\mathrm{y}_{\mathrm{it}}$, 16. 1[0.00] for $\Delta y_{i t},-1.1[0.00]$ for $\mathrm{rr}_{\mathrm{it}},-5.7[0.00]$ for $\Delta \mathrm{rr}_{\mathrm{it}}, 2.5[1.00]$ for reer $_{\mathrm{it}},-30.0$ [0.00] for $\Delta$ reer $\mathrm{rit}_{\mathrm{it}}$ These results suggests that all these variables are I(1). The Augmented Dickey-Fuller results for is -5.12 [0.00] for $\mathrm{Y}_{\text {US, }}^{\mathrm{C}}$ and -4.92 for vix suggesting that they are $\mathrm{I}(0)$. The results are robust to different country groupings and not reported in detail due to space considerations.
} 
Table 4. Exchange Rate Regimes and Real Output: Static Equations

\begin{tabular}{|c|c|c|c|c|c|}
\hline Sample (Eq.) & Constant & $\mathrm{Y}^{\mathrm{C}} \mathrm{US}$ & reer & $\mathrm{rr}$ & Statistics \\
\hline All (4.1) & $\begin{array}{l}3.270 \\
(0.123)^{* *}\end{array}$ & $\begin{array}{l}1.467 \\
(0.265)^{* *}\end{array}$ & $\begin{array}{l}0.309 \\
(0.027) * *\end{array}$ & $\begin{array}{l}-0.169 \\
(0.051)^{* *}\end{array}$ & $\begin{array}{l}\mathrm{F}=1149 \quad[0.00], \mathrm{R}^{2}=0.94 \mathrm{~N}=48, \\
\mathrm{NT}=3792, \mathrm{KaO}=-7.2[0.00], \mathrm{LLC}=- \\
9.45[0.00]\end{array}$ \\
\hline $\mathrm{AE} \quad(4.2)$ & $\begin{array}{l}2.709 \\
(0.222)^{* *}\end{array}$ & $\begin{array}{l}2.212 \\
(0.327)^{* *}\end{array}$ & $\begin{array}{l}0.416 \\
(0.048) * *\end{array}$ & $\begin{array}{l}-0.329 \\
(0.071)^{* *}\end{array}$ & $\begin{array}{l}\mathrm{F}=315.8[0.00], \mathrm{R}^{2}=0.79, \mathrm{~N}=20, \\
\mathrm{NT}=1838, \mathrm{KaO}=-7.7[0.00], \mathrm{LLC}=- \\
8.28[0.00]\end{array}$ \\
\hline EME (4.3) & $\begin{array}{l}3.455 \\
(0.158)^{* *}\end{array}$ & $\begin{array}{l}0.864 \\
(0.408) * *\end{array}$ & $\begin{array}{l}0.283 \\
(0.035) * *\end{array}$ & $\begin{array}{l}-0.080 \\
(0.073)\end{array}$ & $\begin{array}{l}F=1360[0.05], R^{2}=0.96, \quad N=28, \\
N T=1954, \mathrm{KaO}=-3.9[0.00], \mathrm{LLC}=- \\
4.70[0.00]\end{array}$ \\
\hline EME (4.4) & $\begin{array}{l}3.194 \\
(0.154)^{* *}\end{array}$ & $\begin{array}{l}0.978 \\
(0.419) * *\end{array}$ & $\begin{array}{l}0.349 \\
(0.034) * *\end{array}$ & & $\begin{array}{l}\mathrm{F}=1769.0[0.00], \mathrm{R}^{2}=0.96, \mathrm{~N}=28, \\
\mathrm{NT}=2105, \mathrm{KaO}=-7.1[0.00], \mathrm{LLC}=- \\
3.43[0.00]\end{array}$ \\
\hline $\begin{array}{l}\text { AE (4.5) } \\
\text { Managed }\end{array}$ & $\begin{array}{l}2.241 \\
(0.361)^{* *}\end{array}$ & $\begin{array}{l}2.695 \\
(0.391)^{* *}\end{array}$ & $\begin{array}{l}0.532 \\
(0.079) * *\end{array}$ & $\begin{array}{l}-2.191 \\
(0.208) * *\end{array}$ & $\begin{array}{l}\mathrm{F}=404.1[0.00], \mathrm{R}^{2}=0.87, \mathrm{~N}=17, \\
\mathrm{NT}=1163, \mathrm{KaO}=-7.1[0.00], \mathrm{LLC}= \\
\mathrm{NA}\end{array}$ \\
\hline $\begin{array}{l}\text { AE (4.6) } \\
\text { Flexible }\end{array}$ & $\begin{array}{l}2.689 \\
(0.271)^{* *}\end{array}$ & $\begin{array}{l}1.231 \\
(0.490) * *\end{array}$ & $\begin{array}{l}0.398 \\
(0.059) * *\end{array}$ & $\begin{array}{l}-0.123 \\
(0.068)^{*}\end{array}$ & $\begin{array}{l}\mathrm{F}=13.4[0.00], \mathrm{R}^{2}=0.22, \mathrm{~N}=12, \\
\mathrm{NT}=675, \mathrm{KaO}=-4.2[0.00], \mathrm{LLC}= \\
\mathrm{NA}\end{array}$ \\
\hline $\begin{array}{l}\text { EME (4.7) } \\
\text { Managed }\end{array}$ & $\begin{array}{l}3.818 \\
(0.173)^{* *}\end{array}$ & $\begin{array}{l}1.703 \\
(0.499) * *\end{array}$ & $\begin{array}{l}0.225 \\
(0.038) * *\end{array}$ & $\begin{array}{l}0.042 \\
(0.072)\end{array}$ & $\begin{array}{l}\mathrm{F}=2300.6[0.00], \mathrm{R}^{2}=0.98, \mathrm{~N}=21, \\
\mathrm{NT}=1044, \mathrm{KaO}=-2.9[0.00], \mathrm{LLC}=- \\
3.47[0.00]\end{array}$ \\
\hline $\begin{array}{l}\text { EME (4.8) } \\
\text { Managed }\end{array}$ & $\begin{array}{l}3.389 \\
(0.173)^{* *}\end{array}$ & $\begin{array}{l}1.907 \\
(0.531)^{* *}\end{array}$ & $\begin{array}{l}0.334 \\
(0.038) * *\end{array}$ & & $\begin{array}{l}\mathrm{F}=2723[0.00], \mathrm{R}^{2}=0.98, \mathrm{~N}=21, \\
\mathrm{NT}=1168, \mathrm{Kao}=-2.3[0.00], \mathrm{LLC}=- \\
2.87[0.00]\end{array}$ \\
\hline $\begin{array}{l}\text { EME-EA (4.9) } \\
\text { Managed }\end{array}$ & $\begin{array}{l}3.497 \\
(0.185)^{* *}\end{array}$ & $\begin{array}{l}1.913 \\
(0.644) * *\end{array}$ & $\begin{array}{l}0.369 \\
(0.041) * *\end{array}$ & & $\begin{array}{l}\mathrm{F}=4621 \quad[0.00], \mathrm{R}^{2}=0.99, \mathrm{~N}=12, \\
\mathrm{NT}=726, \mathrm{KaO}=-2.9[0.00], \mathrm{LLC}=- \\
1.60[0.05]\end{array}$ \\
\hline $\begin{array}{l}\text { EME East Asia } \\
(4.10) \\
\text { Managed }\end{array}$ & $\begin{array}{l}3.697 \\
(0.430)^{* *}\end{array}$ & $\begin{array}{l}1.886 \\
(0.925)^{* *}\end{array}$ & $\begin{array}{l}0.171 \\
(0.093)^{*}\end{array}$ & & $\begin{array}{l}\mathrm{F}=4621 \quad[0.00], \mathrm{R}^{2}=0.37, \quad \mathrm{~N}=9, \\
\mathrm{NT}=442, \mathrm{Kao}=-2.0[0.05], \mathrm{LLC}=- \\
3.09[0.00]\end{array}$ \\
\hline $\begin{array}{l}\text { EME (4.11) } \\
\text { Flexible }\end{array}$ & $\begin{array}{l}1.873 \\
(0.287)^{* *}\end{array}$ & $\begin{array}{l}-0.532 \\
(0.546)\end{array}$ & $\begin{array}{l}0.608 \\
(0.063) * *\end{array}$ & $\begin{array}{l}-0.478 \\
(0.148)^{* *}\end{array}$ & $\begin{array}{l}\mathrm{F}=58.2[0.00], \mathrm{R}^{2}=0.57, \mathrm{~N}=18, \\
\mathrm{NT}=910, \mathrm{KaO}=-2.8[0.00], \mathrm{LLC}=- \\
3.8[0.00]\end{array}$ \\
\hline $\begin{array}{l}\text { EME (4.12) } \\
\text { Flexible }\end{array}$ & $\begin{array}{l}1.913 \\
(0.284)^{* *}\end{array}$ & & $\begin{array}{l}0.599 \\
(0.063) * *\end{array}$ & $\begin{array}{l}-0.478 \\
(0.148)^{* *}\end{array}$ & $\begin{array}{l}\mathrm{F}=61.2[0.00], \mathrm{R}^{2}=0.57, \mathrm{~N}=18, \\
\mathrm{NT}=910, \mathrm{KaO}=-2.9[0.00], \mathrm{LLC}=- \\
3.13\end{array}$ \\
\hline
\end{tabular}

Notes: The values in parentheses are the standard errors. * and $* *$ denote the significance at the 10 and $5 \%$, respectively. $\mathrm{F}$ is the $\mathrm{F}$ statistic to test the null hypothesis that all the slope coefficients are jointly zero. N and NT are, correspondingly, the numbers of countries and observations for the sample. Kao is the panel ADF statistics to test the null of no panel cointegration proposed by Kao (1999). LLC is the Levin, $\mathrm{Li}$ and Chu (2002) panel unit root test for the equation residuals. NA for LLC denotes that the test statistic (along with the alternative unit root tests) cannot be computed due to the gaps in the residuals data with the presence of ERR changes in the sample. The optimum lag lengths for the tests are chosen by the AIC. The values in brackets [.] are the p-values for the corresponding null hypothesis. 
The results for $\mathrm{AE}$ and $\mathrm{EME}$ are different from each other with the former having considerably larger coefficient estimates in absolute value (eqs. 4.2, 4.3 and 4.4). Consistent with the fact that their integration with the world economy, and thus the US, is much higher, the impact of the US cycle is more than twice in AE than the EME. Real interest rate changes, on the other hand, may be interpreted not to affect the long-run growth significantly in EME. These results, however, may not be invariant to the prevailing de facto ERR.

The impacts of both foreign and domestic variables substantially decrease but remains statistically significant with exchange rate flexibility in $\mathrm{AE}$ (eqs. 4.5 and 4.6). Consistent with an argument that interest rates are often used as an effective policy tool of exchange rate management, the interest rate coefficient in AE is substantially larger under managed ERR than flexible ERR. For the EME samples, on the other hand, interest rates are found to be not effective under managed ERR (eq. 4.8). This may be plausible as these countries often prefer direct foreign exchange market interventions and other money market instruments including direct or indirect capital controls to manage exchange rates. The results for East Asian and the other EME under managed ERR are essentially the same except the evidence that the positive impact of real exchange rate appreciations on real output is much less for the East Asian EME (eqs. 4.9 and 4.10). Under flexible ERR, only domestic variables (reer and rr) appear to matter in the long-run ${ }^{14}$ (eqs. 4.11 and 4.12) supporting the argument that these regimes provide an effective buffer against external shocks in EME (Edwards, 2011). Interest rate decreases and real exchange rate appreciations are found to be expansionary under flexible ERR. The positive impact of real exchange rate appreciations on growth may suggest that the balance sheet affect due to financial dollarization dominates the international competitiveness affect in EME (Calvo and Reinhart, 2002 and Frankel, 2005).

We now proceed with the estimation of the dynamic model given by (3). We initially estimated (3) with the ARDL lag length chosen as 2 and by applying a dataacceptable sequential reduction of statistically insignificant variables we obtained the parsimonious panel fixed effect estimation results for different country groupings and ERRs reported by Table 5. In the table, "managed" defines the episodes for ERR1 (hard pegs) and ERR2 (limited flexibility) whilst "flexible" denotes the ERR3 (managed floating) and ERR4 (freely floating) regimes.

\footnotetext{
${ }^{14}$ The results are found to be essentially the same for the East Asian and the other EME and not reported to save the space.
} 
Table 5. Exchange Rate Regimes and Growth Cycles: PARDL Results

\begin{tabular}{|c|c|c|c|c|c|c|c|}
\hline $\begin{array}{l}\text { Sample (Eq.) } \\
\text { ERR }\end{array}$ & All (5.1) & $\mathrm{AE} \quad(5.2)$ & EME (5.3) & $\begin{array}{l}\text { AE (5.4) } \\
\text { Managed }\end{array}$ & $\begin{array}{l}\text { AE (5.5) } \\
\text { Flexible }\end{array}$ & $\begin{array}{l}\text { EME (5.6) } \\
\text { Managed }\end{array}$ & $\begin{array}{l}\text { EME (5.7) } \\
\text { Flexible }\end{array}$ \\
\hline ec. eq. & 4.1 & 4.2 & 4.4 & 4.5 & 4.7 & 4.9 & 4.11 \\
\hline Constant & $\begin{array}{l}0.020 \\
(0.002) * *\end{array}$ & $\begin{array}{l}0.013 \\
(0.002) * *\end{array}$ & $\begin{array}{l}0.040 \\
(0.004)^{* *}\end{array}$ & $\begin{array}{l}0.012 \\
(0.003) * *\end{array}$ & $\begin{array}{l}0.016 \\
(0.004)^{* *}\end{array}$ & $\begin{array}{l}0.031 \\
(0.005)^{* *}\end{array}$ & $\begin{array}{l}0.033 \\
(0.006)^{* *}\end{array}$ \\
\hline$e c_{i, t-1}$ & $\begin{array}{l}-0.008 \\
(0.001)^{* *}\end{array}$ & $\begin{array}{l}-0.008 \\
(0.001)^{* *}\end{array}$ & $\begin{array}{l}-0.006 \\
(0.002)^{* *}\end{array}$ & $\begin{array}{l}-0.010 \\
(0.002)^{* *}\end{array}$ & $\begin{array}{l}-0.009 \\
(0.002)^{* *}\end{array}$ & $\begin{array}{l}-0.006 \\
(0.002)^{* *}\end{array}$ & $\begin{array}{l}-0.005 \\
(0.003)^{*}\end{array}$ \\
\hline$\Delta \mathrm{Y}_{\mathrm{t}}^{\mathrm{USC}}$ & $\begin{array}{l}0.483 \\
(0.047)^{* *}\end{array}$ & $\begin{array}{l}0.381 \\
(0.046) * *\end{array}$ & $\begin{array}{l}0.567 \\
(0.076)^{* *}\end{array}$ & $\begin{array}{l}0.346 \\
(0.057) * *\end{array}$ & $\begin{array}{l}0.457 \\
(0.074) * *\end{array}$ & $\begin{array}{l}0.587 \\
(0.098)^{* *}\end{array}$ & $\begin{array}{l}0.511 \\
(0.117)^{* *}\end{array}$ \\
\hline$\Delta \mathrm{Y}_{\mathrm{t}-1}^{\mathrm{USC}}$ & $\begin{array}{l}0.468 \\
(0.046) * *\end{array}$ & $\begin{array}{l}0.360 \\
(0.047) * *\end{array}$ & $\begin{array}{l}0.415 \\
(0.076) * *\end{array}$ & $\begin{array}{l}0.376 \\
(0.059) * *\end{array}$ & $\begin{array}{l}0.335 \\
(0.076)^{* *}\end{array}$ & $\begin{array}{l}0.580 \\
(0.095) * *\end{array}$ & $\begin{array}{l}0.409 \\
(0.114) * *\end{array}$ \\
\hline$\Delta \mathrm{rr}_{\mathrm{i}, \mathrm{t}-1}$ & & & & $\begin{array}{l}0.023 \\
(0.010) * * \\
\end{array}$ & & & \\
\hline$\Delta Y_{\mathrm{i}, \mathrm{t}-1}$ & $\begin{array}{l}-0.089 \\
(0.016) * *\end{array}$ & $\begin{array}{l}-0.122 \\
(0.023) * *\end{array}$ & $\begin{array}{l}-0.104 \\
(0.021)^{* *}\end{array}$ & & $\begin{array}{l}-0.199 \\
(0.038)^{* *}\end{array}$ & & $\begin{array}{l}-0.221 \\
(0.033)^{* *}\end{array}$ \\
\hline $\operatorname{vix}_{t}$ & $\begin{array}{l}-0.004 \\
(0.001)^{* *}\end{array}$ & $\begin{array}{l}-0.003 \\
(0.001)^{* *}\end{array}$ & $\begin{array}{l}-0.003 \\
(0.001)^{* *}\end{array}$ & & & $\begin{array}{l}-0.007 \\
(0.001)^{* *}\end{array}$ & $\begin{array}{l}-0.007 \\
(0.002)^{* *}\end{array}$ \\
\hline $\operatorname{vix}_{t-1}$ & & & $\begin{array}{l}-0.006 \\
(0.002)^{* *}\end{array}$ & $\begin{array}{l}-0.002 \\
(0.001)^{* *}\end{array}$ & $\begin{array}{l}-0.003 \\
(0.001)^{* *}\end{array}$ & & \\
\hline \multirow[t]{4}{*}{ Statistics } & $\mathrm{N}=48$ & $\mathrm{~N}=20$ & $\mathrm{~N}=28$ & $\mathrm{~N}=17$ & $\mathrm{~N}=11$ & $\mathrm{~N}=21$ & $\mathrm{~N}=18$ \\
\hline & $\mathrm{NT}=3746$ & $\mathrm{NT}=1819$ & $\mathrm{NT}=2073$ & $\mathrm{NT}=1158$ & $\mathrm{NT}=663$ & $\mathrm{NT}=1156$ & $\mathrm{NT}=896$ \\
\hline & $\mathrm{R}^{2}=0.15$ & $\mathrm{R}^{2}=0.15$ & $\mathrm{R}^{2}=0.13$ & $\mathrm{R}^{2}=0.17$ & $\mathrm{R}^{2}=0.17$ & $\mathrm{R}^{2}=0.16$ & $\mathrm{R}^{2}=0.13$ \\
\hline & $\begin{array}{l}\mathrm{F}=12.1 \\
{[0.00]}\end{array}$ & $\begin{array}{l}F=13.4 \\
{[0.00]}\end{array}$ & $\begin{array}{l}\mathrm{F}=9.2 \\
{[0.00]}\end{array}$ & $\begin{array}{l}F=10.7 \\
{[0.00]}\end{array}$ & $\begin{array}{l}\mathrm{F}=9.2 \\
{[0.00]}\end{array}$ & $\begin{array}{l}F=8.7 \\
{[0.00]}\end{array}$ & $\begin{array}{l}\mathrm{F}=5.7 \\
{[0.00]}\end{array}$ \\
\hline
\end{tabular}

Notes: The values in parentheses are the standard errors. $*$ and $* *$ denote the significance at the 10 and $5 \%$, respectively. $\mathrm{F}$ is the $\mathrm{F}$ statistic to test the null hypothesis that all the slope coefficients are jointly zero and [.] reports the p-value of the F. N and NT are, correspondingly, the numbers of countries and observations for the sample.

In all the equations of Table 5, the error/equilibrium correction (ec) terms are negative and significant suggesting the adjustment of growth to establish equilibrium. The results strongly suggest that the real external and financial shocks proxied, respectively by the US cycle and the VIX are important determinants of growth cycles of all country groupings and ERRs. This supports the crucial importance of external factors on the evolution of business cycles of EME (Calvo, et al., 1993; Perri and Neumeyer, 2005; Izquierdo, et al., 2008; Kose, et al., 2012 and Kose, et al., 2013). The results, on the other hand, suggest that the same is the case also for AE. The results by Table 5 suggest that tightening of the global liquidity or a decrease in the risk appetite in international financial markets as represented by an increase in VIX leads to a decrease in real output in 
EME and AE. This impact is relatively higher in EME than AE as the impact of tighter international financial conditions may be expected to be lower in $\mathrm{AE}$ due to flight to quality or safety behavior of financial assets. The impact of real external shocks is also relatively higher for EME in the short-run almost regardless of the prevailing de facto ERR. Domestic variables (short-term interest rates) appear to matter only for AE under managed ERR. This may not necessarily support an hypothesis that domestic conditions do not affect business cycles in the other samples as their impacts may be already contained in the static long-run equations presented by Table 4 .

\section{Concluding Remarks}

ERRs matter for growth especially in EME according to many studies in the literature including Husain et al., (2005), Edwards (2011) and IMF (2014). This contrasts with the classic neutrality argument that business cycles are invariant to different ERRs (Baxter and Stockman, 1989 and Flood and Rose, 1995). The neutrality argument may become more puzzling when we consider that different ERR directly affect the ability of independent monetary policy of countries under international capital mobility and offer different insulation mechanisms from external shocks. This paper attempted to investigate this puzzle.

Compared to $\mathrm{AE}, \mathrm{EME}$ tend to experience much deeper recessions and relatively steeper expansions during almost the same duration. Both the pains of contractions and the gain of expansions are almost the twice in EME compared to AE. ERRs appear to be important for the evolution of classical business cycles in both AE and EME. Our results suggest that the probability of expansion increases with ERR flexibility and better global real conditions for the EME sample excluding the East Asian countries. For the East Asian countries managed (pegs, managed float and limited flexibility) regimes, the performance of each is essentially the same with those of the others, appear to perform better than the floating regime. The ERR neutrality argument is not supported even for $\mathrm{AE}$ as floating ERR performs better than the managed regimes. Consequently, our answer is "yes" to both of the first two questions stated in the "Introduction" part of this study. ERR matter for classical business cycles in both AE and EME and better global real conditions increases the probability of expansions in most of our samples. For the third question, our preliminary answer is "yes", as the impact of external factors often decreases with ERR flexibility. 
The results of this paper also suggest that both the domestic and external variables significantly affect the evolution of real income in the whole sample of countries in the long-run. Real exchange rate appreciations appear to be expansionary whilst real interest rate increase is contractionary for this sample. The impacts of both foreign and domestic variables substantially decrease but remains statistically significant with exchange rate flexibility in AE. Consistent with an argument that interest rates are often used as an effective policy tool of exchange rate management, the impact of interest rates tends to be substantially larger in AE under managed ERR than flexible ERR. For the EME samples, on the other hand, interest rates are found to be not effective under managed ERR. This may be plausible as these countries often prefer direct foreign exchange market interventions and other money market instruments including direct or indirect capital controls to manage exchange rates. The positive impact of real exchange rate appreciations on real output is found to be much less for the East Asian EME than the other EME. Under flexible ERR, only domestic variables appear to matter in the long-run supporting the argument that floating regimes provide an effective buffer against external shocks in EME (Edwards, 2011). Interest rate decreases and real exchange rate appreciations are found to be expansionary under flexible ERR. The positive impact of real exchange rate appreciations on growth may suggest that the balance sheet affect due to financial dollarization dominates the international competitiveness affect in EME. To conclude, our answer to the final "introductory" question is "No". The impacts of domestic and external factors on business cycles (growth cycles) are not invariant to the prevailing ERR. That is, prevailing ERRs matter both the evolution and determinants of classical and growth cycles in EME and AE. 


\section{References}

Aguiar, M. and G. Gopinath (2007) Emerging market business cycles: The cycle is the trend, Journal of Political Economy, 115(1), 69-102.

Altug, S. and F. Canova (2012) Do institutions and culture matter for business cycles?, Open Economies Review, 25, 93-122.

Altug, S., Neyapti, B. and M. Emin (2012) Institutions and business Cycles, International Finance, 15(3), 347-366.

Baxter, M. and A. Stockman (1989) Business cycles and the exchange rate system: Some international evidence, Journal of Monetary Economics, 23, 377-401.

Boschi, M. and A. Girardi (2011) The contribution of domestic, regional and international factors to Latin America's business cycle, Economic Modelling, 28, 1235-1246.

Broda, C. (2004) Terms of trade and exchange rate regimes in developing countries, Journal of International Economics, 63(1), 31-58.

Bry, G. and C. Boschan (1971) Cyclical analysis of time series: Selected procedures and computer programs. New York, NBER.

Burns, A.F. and W.C. Mitchell (1946) Measuring Business Cycles, NBER.

Calderón, C. and J.R. Fuentes (2014) Have business cycles changed over the last two decades? An empirical investigation, Forthcoming, Journal of Development Economics.

Calvo, G. A., L. Leiderman and C.M. Reinhart (1993) Capital inflows and real exchange rate appreciation in Latin America - The role of external factors, International Monetary Fund Staff Papers, 40(1), 108-51.

Calvo, G. A. and C.M. Reinhart (2002) Fear of floating, Quarterly Journal of Economics, 117(2), 379-408.

Claessens, S., Kose,.A. and M.E. Terrones (2012) How do business and financial cycles interact?, Journal of International Economics, 87, 178-190.

Cesa-Bianchi, A., Pesaran, M.H., Rebucci, A. and T.T Xu (2012) China's Eemergence in the world Economy and business cycles in Latin America, Economia, Journal of the Latin American and Caribbean Economic Association, 12, 1-75.

Chudik, A. and M.H. Pesaran (2013) Common correlated effects estimation of heterogeneous dynamic panel data models with weakly exogenous regressors, Federal Reserve Bank of Dallas, Globalization and Monetary Policy Institute Working Paper No. 146.

Crucini, M.J., Köse, A.M., and C. Otrok (2011) What are the driving forces of international business cycles?, Review of Economic, Dynamics, 14,156-175.

Di Giovanni, J. and J.C. Shambaugh (2008) The impact of foreign interest rates on the economy: The role of the exchange rate regime, Journal of International Economics, 74, 341-361

Edwards, S. (2011) Exchange rates in emerging countries: Eleven empirical regularities from Latin America and East Asia, Open Economies Review, 22(4), 533-63.

Edwards, S. and E. Levy Yeyati (2005) Flexible exchange rates as shock absorbers, European Economic Review, 49(8), 2079-2105.

Fischer, S. (2008) Mundell-Fleming Lecture: Exchange rate systems, surveillance, and advice, IMF Staff Papers, 55, 367-383.

Flood, R.P. and A.K. Rose (1995) Fixing exchange rates: A virtual quest for fundamentals, The Journal of Monetary Economics, 36(1), 3-37.

Frankel, J.A. (2005) Mundell-Fleming Lecture: Contractionary Currency Crashes in developing countries, IMF Staff Papers, 55, 2, 149-192.

Frankel, J.A. (2011) Monetary policy in emerging markets, Handbook of Monetary Economics, Vol. 3, Chapter 25, North Holland: Elsevier. 
Ghosh, A.R., Ostry, J.D. and S.Q., Mahvash (2014) Exchange rate management and crisis susceptibility: A reassessment, IMF Working Papers, 14/11.

Gonzalez-Rozada, M. and E. Levy-Yeyati (2008) Global factors and emerging market spreads, The Economic Journal, 118(533), 1917-1936.

Harding, D. and A. Pagan (2002) Dissecting the cycle: A methodological investigation, Journal of Monetary Economics, 49, 365-381.

Harding, D. and A. Pagan (2002) A Suggested Framework for classsifying the modes of cycle research, Journal of Applied Econometrics, 20, 151-159.

Hirata, H., Köse, A. and C. Otrok (2013) Regionalization vs. Globalization, IMF Working Papers, 13/19

Husain, A.M., Mody, A. and K.S. Rogoff (2005) Exchange rate regime durability and performance in developing versus advanced economies, Journal of Monetary Economics, 52, 35-64

Ilzetzki, E., C. Reinhart and K.S. Rogoff (2008) Exchange rate arrangements entering the 21st Century: Which Aanchor will hold?, Working Paper, University of Maryland and Harvard University.

Izquierdo, A., Romero, R. and E. Talvi (2008) Booms and busts in Latin America: The role of external factors, Inter-American Development Bank Working Paper 631.

Kao, C. (1999) Spurious regression and residual-based tests for cointegration in panel data, Journal of Econometrics, $90,1-44$.

Kose, M.A., Loungani, P. and M.E. Terrones (2013) From the Global to the National Cycle: An Intricate Liaison, Pacific Economic Review, 18, 387-419.

Kose, A., Otrok, C. and E. S. Prasad (2012) Global Business Cycles: Convergence or Decoupling? International Economic Review, 87, 178-90

Kose, A., Otrok, C. and C. Whiteman (2008) Understanding the evolution of World business cycles, Journal of International Economics, 75,110-130.

Levin, A., Lin, C. F., and C. Chu (2002) Unit root tests in panel data: Asymptotic and finitesample properties, Journal of Econometrics, 108, 1-24.

Levy-Yeyati, E. and F. Sturzenegger (2003), To Float or to Fix: Evidence on the Impact of Exchange Rate Regimes on Growth, American Economic Review, 93 (4), 1178-89.

Levy Yeyati, E. and T. Williams (2012) Emerging economies in the 2000s: Real decoupling and financial recoupling, Journal of International Money and Finance, 31, 2102-2126.

Özatay,F., Özmen, E. and G. Şahinbeyoglu (2009) Emerging market sovereign spreads, global financial conditions and U.S. macroeconomic news, Economic Modelling, 26, 526-531.

Perri, F. and P.A. Neumeyer. 2005. "Business Cycles in Emerging Economies: The Role of Interest Rates." Journal of Monetary Economics, 52(2), 345-80.

Pesaran, M.H, Schuermann, T. and Weiner, S.M. (2004) Modelling regional interdependencies using a global error correcting macroeconometric model, Journal of Business and Economic Statistics, 22, 129-162.

Pesaran, M.H.; Y.C. Shin and R.J. Smith. 2001. "Bounds Testing Approaches to the Analysis of Level Relationships." Journal of Applied Econometrics, 16(3), 289-326.

Pesaran, M.H., Shin, Y.C. and R.P. Smith (1999) Pooled Mean Group Estimation of Dynamic Heterogeneous Panels, Journal of the American Statistical Association, 94(446), 62134.

Rabanal, P., Rubio-Ramirez, J.F. and V. Tuesta (2011) Cointegrated TFP processes and international business cycles, Journal of Monetary Economics, 58, 156-171.

Rey, H. (2013) Dilemma not Trilemma: The Global Financial Cycle and Monetary Policy Independence, Paper presented at the 25th Jackson Hole symposium, Wyoming, August 2013. 
Rose, A.K. (2011) Exchange Rate Regimes in the Modern Era: Fixed, Floating, and Flaky, Journal of Economic Literature, 49(3), 652-72.

Schmitt-Grohé, S. and M. Uribe (2011) Business cycles with a common trend in neutral and investment-specific productivity, Review of Economic Dynamics, 14, 122-135. 